\title{
Evaluation of Medicinal Values of Gymnopetalum chinense (Lour.) Merr., a Lesser Known Cucurbit from Eastern Ghats of India
}

\author{
Sanjeet Kumar', Gitishree Das², Han-Seung Shin ${ }^{3}$, Pradeep Kumar ${ }^{4 *}$ and Jayanta Kumar \\ Patra $^{2^{*}}$. \\ ${ }^{1}$ Ambika Prasad Research Foundation, Cuttack, Odisha, India; ${ }^{2}$ Dongguk University-Seoul, Ilsandong-gu, Goyang- \\ si, Gyeonggi, Republic of Korea - Research Institute of Biotechnology \& Medical Converged Science, , Goyang-si, \\ Gyeongido, Korea (the Republic of); ${ }^{3}$ Dongguk University-Seoul, Ilsandong-gu, Goyang, Republic of Korea- \\ Department of Food Science and Biotechnology, Goyang-si, Gyeongido, Korea (the Republic of); ${ }^{4}$ North Eastern \\ Regional Institute of Science and Technology (Deemed University), Nirjuli-791109, Arunachal Pradesh, India - \\ Department of Forestry, Arunachal Pradesh, India.
}

\begin{abstract}
The in vitro antimicrobial activity of Gymnopetulum chinense (Cucurbitaceae), a lesser known climber of Eastern Ghats and recently recorded species from Odisha, India was studied against five selected human pathogenic bacteria (Streptococcus mutans, S. pyogenes, Vibrio cholerae, Shigella flexneri and Salmonella typhi), by agar well diffusion (AWD), disc diffusion (DD) and broth dilution methods. Different solvent extracts were prepared from the leaves of $G$. chinense using various solvents viz. n-hexane, chloroform, methanol, acetone and aqueous. The nomenclature, detailed description and photographs of the plant are provided to facilitate its easy identification. The leaf extract showed presence of phenolic compounds, tannin, saponin, flavonoids and glycosides. It was examined that methanol extract showed highest zone of inhibition (16.66 mm) against $S$. pyogenes using DD assay. Similar results were examined as lowest MIC values were found with methanol leaf extract against $S$. pyogenes and S. mutans $(200 \mu \mathrm{g} / \mathrm{ml})$. Present study showed first report of this plant as natural antibacterial agents and highlights the importance of $G$. chinense in curing the bacterial infections.
\end{abstract}

Key-words: Antibacterial activity, Gymnopetulum chinense, Cucurbits, Streptococcus pyogenes, Antimicrobial resistance

\footnotetext{
*Author for correspondence: jkpatra@dongguk.edu; pkbiotech@gmail.com
} 


\section{INTRODUCTION}

Uses of antibiotics during $20^{\text {th }}$ century have substantially reduced the threat of infectious diseases (Gould 2008). Nevertheless, over the years, there has been a decrease in microbial susceptibility to existing antimicrobial agents responsible for critical point drug resistance in healthcare departments and in communities. ${ }^{1}$ In fact the theme of the World Health Day 2011 was "Antimicrobial resistance: no action today, no cure tomorrow". ${ }^{2}$ It is a big problem in pharmaceutical industry and for future health care. Recently different researchers have reported the urgent need for new antimicrobial agents to replenish the arsenal of anti-infective agents or drugs. It is reported that, on an average, two or three antibiotics are launched each year. ${ }^{3}$ After a downturn in that pace in recent decades, the pace is again quickening as scientists realize that the effective life span of any antibiotics is limited. ${ }^{1,4-6}$ Therefore, it is necessary to know more about antimicrobial resistance (AMR), the mechanisms of action and screening of secondary metabolites from the biowealth. ${ }^{7}$

Finding healing powers in plants is an ancient idea. People of all continents have been long appling poultices and ambibed infusion of hundreds, if not thousands, of indigenous plants, dating back to prehistory. There is evidence that Neanderthals living 60,000 years ago in present-day Iraq used plants against infections such as Hollyhock. These plants are still widely used in ethno-medicine around the world. It is estimated that there are 250,000 to 500,000 species of plants on earth. A relatively small percentage ( 1 to $10 \%$ ) of these are used as foods by both humans and other animal species. It is possible that even more are used for medicinal purposes. Hippocrates mentioned 300 to 400 medicinal plants used in different diseases in the late fifth century B.C. In the first century A.D., Dioscorides wrote "De Materia Medica", a medicinal plant catalog which become the prototype for modern pharmacopoeias. The Bible offers descriptions of approximately 30 healing plants. Indeed frankincense and myrrh probably enjoyed their status of great worth due to their properties. Reported to have antiseptic properties, they were even employed as mouthwashes. During the Dark Age, the Arab world continued to excavate their own older works and to build upon them. Of course, Asian cultures particularly Indian Vedas were also busy compiling their own pharmacopeia. Still, in modern era, the tribal communities around the world have been using the plant extracts against microbial infections ${ }^{8,9}$.

Plant materials are of wide use in traditional systems of medicine, and in several communities of the developing world. ${ }^{8}$ They are the only resources available for the treatment of different microbial infections among many rural and tribal communities. Most of the common plants have been reported to have antimicrobial activity, still a number of unexplored wild plants are available in the forests having good ethnic values as traditional medicines.

There is need for the screening of bioactive compounds present in such plants and the antimicrobial activities of their extracts. ${ }^{10}$ Even though several plant species have reported to be used for screening of antimicrobial agents in Odisha, studies on the same in cucurbits is not well documented. So far about 21 species of cucurbits are reported to occur in the geographical area of the state. ${ }^{11-13}$

Among them, the genus Gymnoptalum Arn. belonging to this family has four species which are distributed in Tropical Asia from India to Moluccas. ${ }^{14}$ In India, this genus is represented by three species, and none of them were reported from Odisha till 2012. ${ }^{15-18}$ Under this genus G. cochinchinensis (Lour.) was reported for the first time by Mandal et al. ${ }^{12}$ from Similipal Biosphere Reserve making the first generic record of this family in Odisha, India. Later another species, G. chinense (Figure 1) was also reported by Pradeep et al. ${ }^{13}$ from Dhenkanal district of Odisha, 
India in the mainland and recently the same species is found by the authors in coastal areas making its adaptability to variable climate and environment.

Therefore, keeping in view of the adaptability of this plant to changing environment, a need was felt to screen the antimicrobial potential of this cucurbit from Odisha. This plant has also unreported antibacterial properties and unexplored the other therapeutic values. Hence, in the present study, an attempt was made to evaluate the qualitative phytochemical analysis and antibacterial activities of the plant which highlights the pharmacological importance of the unexplored wild plant.

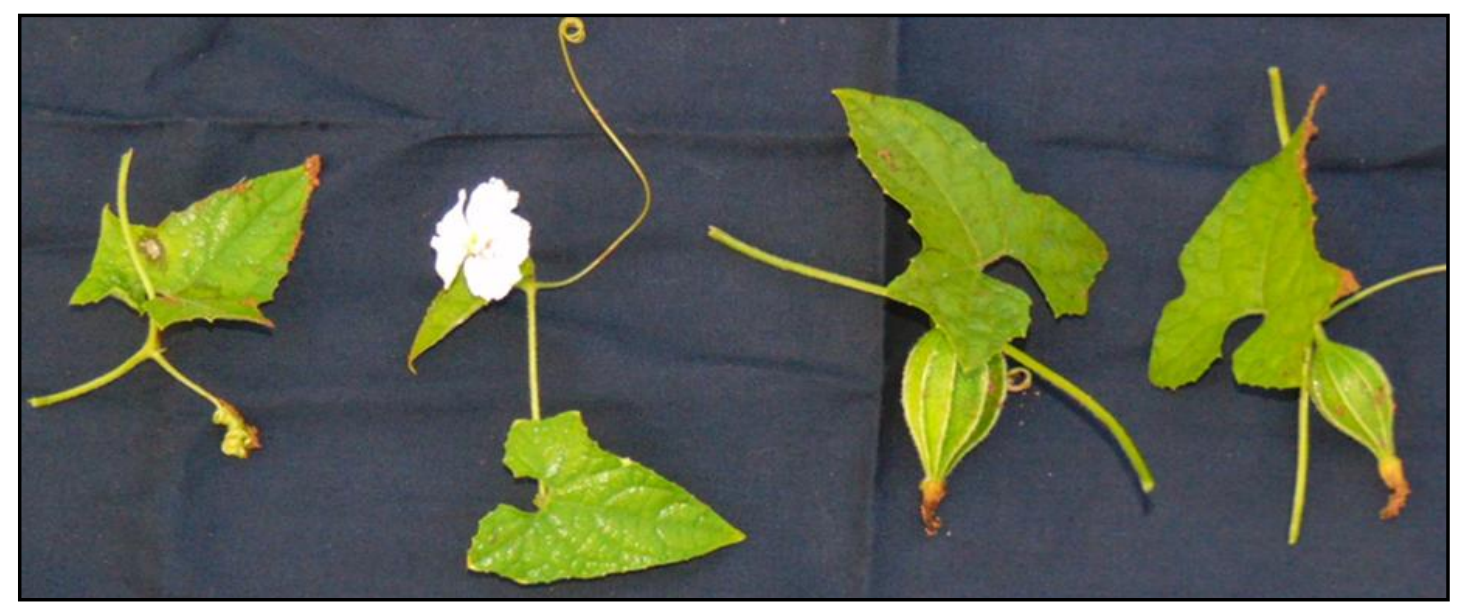

Fig. 1: Pictorial presentation of Gymnopetalum chinense (Fruits, leaves and flower)

\section{MATERIALS AND METHODS}

\section{Reagents and chemicals}

All used reagents and chemicals were of analytical grade. The diluents used in the present work were sterile distilled water (Merck, Milipore, US). DMSO (Merck B.No- 206421), Agar Agar (Qualigens B.No- 66156906), Peptone (Qualigens B.No. 3318/1 6805-1), Beef Extract (Qualigens B.No. 4302/1 6810-1), Sterilized Hi Media flexiloop 2 (2.2 mm, PW012), Trypticase soya broth (Himedia-LQ508) were used.

\section{Plant description}

Description: Monoecious climbing herb, stems slender, angular, sulcate, scabroushairy; tendrils simple, filiform. Leaves membranous; scabrous, ovate-cordate, angled; base deeply cordate; apex acuminate; margin undulate, sparsely dentate; probract absent. Male inflorescence raceme; bracteates; flowers solitary, peduncle long, bract prominent, obovate, incise-serrate. Male flower solitary; calyx tube elongate, villous, wider at apex; sepals linear; stamens-3, inserted. Female flower solitary, in the same or different axil as male inflorescence. Ovary pubescent; narrowly ellipsoid. Stigma 3. Fruits are ovoid-oblong and ribbed (Figure 1). Phenology: Flowering: October -December, Fruiting: November - January.

\section{Collection of plant materials}

Leaves of G. chinense (Figure 1) were collected from the coastal part of Odisha, India. Collected leaves were washed properly and were cut into small pieces and left for air drying. ${ }^{19}$ The dried materials were crushed to powder with mechanical 
device and were kept it in air tight container for phytochemical screening and antibacterial activity.

\section{Preparation of plant extracts}

As per the polarity index five solvents (n-hexane, chloroform, acetone, methanol and aqueous) were selected for extraction. Soxhlet method and percolation were adopted to obtain the plant extracts ${ }^{20}$. The plant parts of experimental plant leaves were collected and dried at room temperature under shade and were powdered after drying using mechanical devices. The powder of leaves was poured in the thimble at the ratio of $20 \mathrm{~g}$ per $250 \mathrm{~mL}$ of solvents at the standard temperature. The residues were collected and left for air drying and dried crude extracts were stored in refrigerator for further experimental work.

\section{Qualitative detection of bioactive compounds}

Phyto-chemical experiments were carried out on n-Hexane, chloroform, acetone, methanol, and aqueous extracts of leaves of $G$. chinense using standard procedure to detect the bioactive compounds as described by different workers. ${ }^{19,21,22}$

Test of Tannin: extracts was taken in a test tube and 3-5 drops of $0.1 \%$ ferric chloride solution were added. The brownish green or blue black colouration indicated the presence of tannins.

Test for Saponin: Extract was boiled in distilled water and filtered with Whatman 42 filter paper. Filtrate was mixed with normal distilled water and shaken vigorously. The stable persistent froth indicated the presence of saponins.

Test of Flavonoids: $6 \mathrm{~mL}$ of dilute ammonium solution was added to portion of the aqueous filtrate of plant extract followed by addition of concentrated sulphuric acid. A yellow colouration indicated the presence of flavonoids.

Test of Glycosides: $0.5 \mathrm{~g}$ of extract was treated with $1 \%$ ferric chloride solution and was put into water bath for 5 minutes at $100{ }^{\circ} \mathrm{C}$. The mixture was cooled and equal volume of benzene was added. The benzene layer was separated and $5 \mathrm{~mL}$ of ammonia solution was added. Formation of rose pink colour indicated the presence of glycosides.

Test of Phenolic compounds: $0.5 \mathrm{~g}$ of extract was treated with 3-5 drops of $1 \%$ ferric chloride solution. Formation of bluish black colouration indicated the presence of phenolic compounds.

\section{Antibacterial activity \\ Media used}

Nutrient broth was used to maintain broth cultures. The constituents of the nutrient broth included $0.5 \mathrm{~g} \mathrm{NaCl}, 0.5 \mathrm{~g}$ peptone and $0.3 \mathrm{~g}$ beef per $100 \mathrm{~mL}$. An additional $1.5 \mathrm{~g}$ of agar made up the nutrient agar medium.

\section{Experiment}

The extracts of experimental plant part was screened for antibacterial activity against two Gram-positive bacteria Streptococcus mutans (MTCC 497) and Streptococcus pyogenes (MTCC 1926); three Gram-negative bacteria Vibrio cholerae (MTCC 3906), Shigella flexneri (MTCC 1457) and Salmonella typhi (MTCC 1252). All used MTCC (Microbial Type Culture Collection) bacterial strains were collected from Institute of Microbial Technology (IMTECH), Chandigarh. Antibacterial activity was done using slight modification of standard 
methods of Agar Well Diffusion assay, ${ }^{23}$ Disc Diffusion method ${ }^{24}$ and Broth dilution assay. ${ }^{25}$ Agar well diffusion method $^{23}$ was followed to test the antibacterial activity of extracts of experimental plant parts against the five bacterial strains. Nutrient agar plates were prepared as per manufacturer's instructions. Wells $(6 \mathrm{~mm})$ were made using sterile borer. Stock solutions of samples were prepared in $100 \%$ DMSO (Sigma) and twofold serial dilutions were made in amount of $100 \mu \mathrm{L}$ per well ranged from $0.5-2.0 \mathrm{mg} / \mathrm{mL} .100 \mu \mathrm{L}$ of samples were added by sterile syringes into the wells in three above mentioned concentration and allowed to diffuse at room temperature for $2 \mathrm{~h}$. Plates were incubated at $35 \pm 2^{\circ} \mathrm{C}$ for 18 - $24 \mathrm{~h}$. Triplicates were maintained and the experiment was repeated thrice. For each replicates the readings (diameter of zone of inhibition in $\mathrm{cm}$ ) were taken and the mean \pm SD values (diameter of zone of inhibition) were recorded. Antibacterial activity using Disc diffusion assay was done using the 6 $\mathrm{mm}$ of disc prepared from whattman filter paper. ${ }^{24}$ Each extracts were dissolved in dimethyl sulfoxide. The sets of three dilutions of crude extracts and standard drugs were prepared. $6 \mathrm{~mm}$ of discs were kept in the drugs for $12 \mathrm{~h}$ before placing to the agar plates. The zones of growth inhibition around the disks were measured after 18 to $24 \mathrm{~h}$ of in incubation at $37{ }^{\circ} \mathrm{C}$ for bacteria. The sensitivities of the microbial species to the plant extracts were determined by measuring the sizes of inhibitory zones (including the diameter of disk) on the agar surface around the disks, and values less than $8 \mathrm{~mm}$ were considered as not active against microorganisms. Mean and SD (standard deviation) was performed to calculate taking triplicate values of zone of inhibition ( $\mathrm{cm}$ for agar well diffusion assay; $\mathrm{mm}$ for disc diffusion) of samples using Excel, Microsoft Corporation-2010, US).

\section{MIC using Broth Dilution assay}

Minimum Inhibitory Concentration (MIC) was evaluated by serial dilution method. ${ }^{25}$ Selected colonies of aforesaid bacteria were picked off to a fresh isolation plate and inoculated in corresponding tubes containing $5 \mathrm{~mL}$ of trypticase soya broth. The broth was incubated for $8 \pm 1 \mathrm{~h}$ at $35 \pm 2{ }^{\circ} \mathrm{C}$ until there was visible growth. Mc Farland No.5 standard and PBS (Phosphate buffer saline) were used to adjust the turbidity to get $10^{5} \mathrm{cfu} / \mathrm{mL}$.

\section{Data Interpretation}

After the incubation, the tubes showing no visible growth after $8 \mathrm{~h}$ till $12 \mathrm{~h}$ were considered to be inhibition of bacteria which represent MIC (minimum inhibitory concentration) values of a respective concentration. Inoculums control showed visible growth due to no antimicrobial agents, whereas the broth control showed no growth due to absence of bacteria. Triplicates were maintained and the experiment was repeated thrice, for each replicates. The readings were taken as foresaid.

\section{RESULTS AND DISCUSSION}

In present investigation, authors could locate ten individuals of $G$. chinense (Figure 1) in three localities of coastal belts of Khurda (Balugaon, Dhuanali and forest rest house of Barbara RF). After critical study and through literature survey, the distribution of this species was extended to coastal districts of Odisha. Its occurrence in Nellore district of Andhra Pradesh ${ }^{18}$ and South Eastern Ghats of Tamil $\mathrm{Nadu}^{26}$ and coastal part (present report) of Odisha confirms the south, western-ward and eastern coastal part extension of its distribution in the country. The field observation and review concluded that it is the new distribution of $G$. chinense in Odisha. 
The phytochemical analysis of leaves of the experimental plant revealed that extracts of $G$. chinense possess various bioactive compounds. It was observed that extract of alkane group not showed any tested compounds whereas alkyl halides group showed presence of saponin only. It was examined that ketones and alcohol group of extracts showed phenolic compound, flavonoid, tannin and saponin (Table 1). The richness of these above compounds provides a base line of the medicinal values of the experimental plant. The flavonoids present in ketone and alcohol (Table 1) showed the potential of the leaves as antifungal activity. ${ }^{27}$ Tannins were present in ketone and alcohol extracts (Table 1) which is also reported to have antifungal activities. ${ }^{28}$ Glycoside was present in alcohol extract (Table 1) which is effective for heart problems. ${ }^{29,30,31 .}$

The evaluation of antibacterial activity showed significant zone of inhibition against selected human pathogens. The zone of inhibition of said extracts against selected microbial strains were more significant using DD assay as compare to AWD assay (Figure 2). Details are listed in Table 2-4. It was observed that, in AWD assay the aqueous extract showed significant activity against both gramnegative and gram-positive bacteria (Table 2) while in the DD assay, methanol extract exhibit highest activity against all tested bacterial strains (Table 3). The photochemical analysis revealed that, both extracts are rich in phenolic compounds, tannin, saponin and flavonoids. It was observed that a very similar activity was noted in both the above cited methods, i.e. extracts significantly inhibits the growth of MTCC 457 and MTCC 926 (Figure 3). The estimation of minimum inhibitory concentration showed lowest inhibitory action $(200 \mu \mathrm{g} / \mathrm{ml})$ against Gram-positive bacteria Streptococcus mutans (MTCC 497) and Streptococcus pyogenes (MTCC 1926) by methanol extract of G. chinense leaves (Figure 4; Table 4). In all used methods, it was noted that methanol showed highest activity against the used bacterial strains followed by aqueous extract; the reason behind this activity might be due to the presence of more antibacterial compounds in the methanol extract. Results of the present study are the first report about the antibacterial potentials of this wild unexplored plant species from Odisha, India.

Table 1: Bioactive compounds detected in the leaves of Gymnopetalum chinense

\begin{tabular}{|c|c|c|c|c|}
\hline Polarity & Formula & Group & Extract & Bioactive compounds \\
\hline \multirow[t]{4}{*}{ Non Polar } & R-H & Alkanes & n-Hexane & ND \\
\hline & $\mathrm{R}-\mathrm{X}$ & Alkyl halides & Chloroform & Saponin \\
\hline & $\mathrm{R}-\mathrm{CO}-\mathrm{R}$ & Ketones & Acetone & $\begin{array}{l}\text { Phenolic compounds, Flavonoids, Tannin and } \\
\text { Saponin }\end{array}$ \\
\hline & $\mathrm{R}-\mathrm{OH}$ & Alcohol & Methanol & $\begin{array}{l}\text { Phenolic compounds, Flavonoids, Tannin, } \\
\text { Saponin and Glycosides }\end{array}$ \\
\hline Polar & \multicolumn{2}{|c|}{ Inorganic compounds } & Aqueous & $\begin{array}{l}\text { Phenolic compounds, Tannin, Saponin, } \\
\text { Flavonoids }\end{array}$ \\
\hline
\end{tabular}

Table 2: Antibacterial activity of leaves extracts of Gymnopetalum chinense by agar well diffusion assay (AWD)

\begin{tabular}{|c|c|c|c|c|c|c|}
\hline \multirow[t]{2}{*}{ Strain(s) } & \multicolumn{5}{|c|}{ Zone of inhibition (mm) } & \multirow[t]{2}{*}{ Extract(s) } \\
\hline & $50 \mu \mathrm{g} / \mathrm{ml}$ & $100 \mu \mathrm{g} / \mathrm{ml}$ & $200 \mu \mathrm{g} / \mathrm{ml}$ & $400 \mu \mathrm{g} / \mathrm{ml}$ & $500 \mu \mathrm{g} / \mathrm{ml}$ & \\
\hline MTCC 3906 & $\mathrm{NI}$ & $\mathrm{NI}$ & NI & $\mathrm{ZI} \leq 0.70$ & $7.40 \pm 0.07$ & \multirow[t]{5}{*}{ Methanol } \\
\hline MTCC 1252 & NI & $\mathrm{ZI}<0.70$ & $\mathrm{ZI} \leq 0.70$ & $7.30 \pm 0.02$ & $8.30 \pm 0.07$ & \\
\hline MTCC 1457 & NI & $\mathrm{ZI}<0.70$ & $\mathrm{ZI} \leq 0.70$ & $8.30 \pm 0.01$ & $10.0 \pm 0.14$ & \\
\hline MTCC 1926 & $\mathrm{ZI}<0.70$ & $\mathrm{ZI} \leq 0.70$ & $7.0 \pm 0.03$ & $9.10 \pm 0.04$ & $10.0 \pm 0.14$ & \\
\hline MTCC 497 & NI & $\mathrm{ZI}<0.70$ & $\mathrm{ZI} \leq 0.70$ & $7.80 \pm 0.03$ & $8.20 \pm 0.21$ & \\
\hline MTCC 3906 & NI & $\mathrm{ZI}<0.70$ & $7.5 \pm 0.03$ & $9.00 \pm 0.03$ & $10.0 \pm 0.07$ & \multirow[t]{4}{*}{ Acetone } \\
\hline MTCC 1252 & NI & $\mathrm{ZI}<0.70$ & $\mathrm{ZI} \leq 0.70$ & $8.0 \pm 0.01$ & $9.0 \pm 0.07$ & \\
\hline MTCC 1457 & NI & $\mathrm{ZI}<0.70$ & $\mathrm{ZI} \leq 0.70$ & $7.0 \pm 0.01$ & $8.5 \pm 0.03$ & \\
\hline MTCC 1926 & $\mathrm{NI}$ & $\mathrm{ZI}<0.70$ & $\mathrm{ZI} \leq 0.70$ & $7.6 \pm 0.03$ & $10.0 \pm 0.10$ & \\
\hline
\end{tabular}


Antibacterial activity of Gymnopetalum chinense

\begin{tabular}{|l|l|l|l|l|l|l|}
\hline MTCC 497 & NI & ZI $<0.70$ & ZI $\leq 0.70$ & $7.8 \pm 0.01$ & $10.0 \pm 0.10$ & \\
\hline MTCC 3906 & NI & NI & NI & NI & $12.0 \pm 0.14$ & Aqueous \\
\hline MTCC 1252 & NI & NI & NI & NI & $10.0 \pm 0.14$ \\
\hline MTCC 1457 & NI & NI & NI & NI & $13.0 \pm 0.14$ \\
\hline MTCC 1926 & NI & NI & NI & NI & $12.0 \pm 0.14$ \\
\hline MTCC 497 & NI & NI & NI & NI & $11.0 \pm 0.21$ & \\
\hline
\end{tabular}

(ZI < 0.70: zone of inhibition is less than $0.70 \mathrm{~cm} ; \mathrm{ZI} \leq 0.70$ : zone of inhibition is less than or equal to 0.70; NI: no inhibition, AWD assay, mean \pm SD, n=3) (MTCC 3906: Vibrio cholerae, MTCC 1252: Salmonella typhi, MTCC 1457: Shigella flexneri, MTCC 1926: Streptococcus pyogenes, MTCC 497: Streptococcus mutans)

Table 3: Antibacterial activity of leaves extracts of Gymnopetalum chinense by Disc diffusion assay (DD)

\begin{tabular}{|c|c|c|c|c|}
\hline \multirow[t]{2}{*}{ Strains } & \multicolumn{3}{|c|}{ Zone of inhibition (in mm) } & \multirow[t]{2}{*}{ Extract(s) } \\
\hline & $10 \mu \mathrm{g} / \mathrm{disc}$ & $20 \mu \mathrm{g} / \mathrm{disc}$ & $30 \mu \mathrm{g} / \mathrm{disc}$ & \\
\hline MTCC 3906 & $\mathrm{ZI}<7.00$ & $9.00 \pm 1.00$ & $14.33 \pm 0.57$ & \multirow[t]{5}{*}{ Methanol } \\
\hline MTCC 1252 & $\mathrm{ZI}<7.00$ & $7.6 \pm 1.52$ & $13.33 \pm 3.05$ & \\
\hline MTCC 1457 & $\mathrm{ZI}<7.00$ & $7.33 \pm 0.76$ & $11.00 \pm 2.64$ & \\
\hline MTCC 1926 & $\mathrm{ZI}<7.00$ & $13.00 \pm 2.06$ & $16.66 \pm 0.57$ & \\
\hline MTCC 497 & $\mathrm{ZI}<7.00$ & $8.66 \pm 1.52$ & $12.33 \pm 2.08$ & \\
\hline MTCC 3906 & $\mathrm{ZI}<7.00$ & $\mathrm{ZI} \leq 7.00$ & $8.66 \pm 1.52$ & \multirow[t]{5}{*}{ Acetone } \\
\hline MTCC 1252 & $\mathrm{ZI}<7.00$ & $\mathrm{ZI} \leq 7.00$ & $9.66 \pm 1.52$ & \\
\hline MTCC 1457 & $\mathrm{ZI}<7.00$ & $\mathrm{ZI} \leq 7.00$ & $9.33 \pm 1.52$ & \\
\hline MTCC 1926 & $\mathrm{ZI}<7.00$ & $8.66 \pm 1.25$ & $10.33 \pm 2.02$ & \\
\hline MTCC 497 & $\mathrm{ZI}<7.00$ & $\mathrm{ZI} \leq 7.00$ & $8.33 \pm 0.76$ & \\
\hline MTCC 3906 & $\mathrm{ZI}<7.00$ & $\mathrm{ZI} \leq 7.00$ & $8.00 \pm 0.50$ & \multirow[t]{5}{*}{ Aqueous } \\
\hline MTCC 1252 & $\mathrm{ZI}<7.00$ & $\mathrm{ZI} \leq 7.00$ & $7.00 \pm 0.50$ & \\
\hline MTCC 1457 & $\mathrm{ZI}<7.00$ & $8.00 \pm 0.00$ & $10.33 \pm 1.52$ & \\
\hline MTCC 1926 & $\mathrm{ZI}<7.00$ & $8.00 \pm 0.00$ & $10.33 \pm 1.04$ & \\
\hline MTCC 497 & $\mathrm{ZI}<7.00$ & $\mathrm{ZI} \leq 7.00$ & $8.33 \pm 1.25$ & \\
\hline
\end{tabular}

(ZI < 0.70: zone of inhibition is less than $0.70 \mathrm{~cm}$; ZI $\leq 0.70$ : zone of inhibition is less than or equal to 0.70; NI: no inhibition, DD assay, mean $\pm \mathrm{SD}, \mathrm{n}=3$ ) (MTCC 3906: Vibrio cholerae, MTCC 1252: Salmonella typhi, MTCC 1457: Shigella flexneri, MTCC 1926: Streptococcus pyogenes, MTCC 497: Streptococcus mutans)

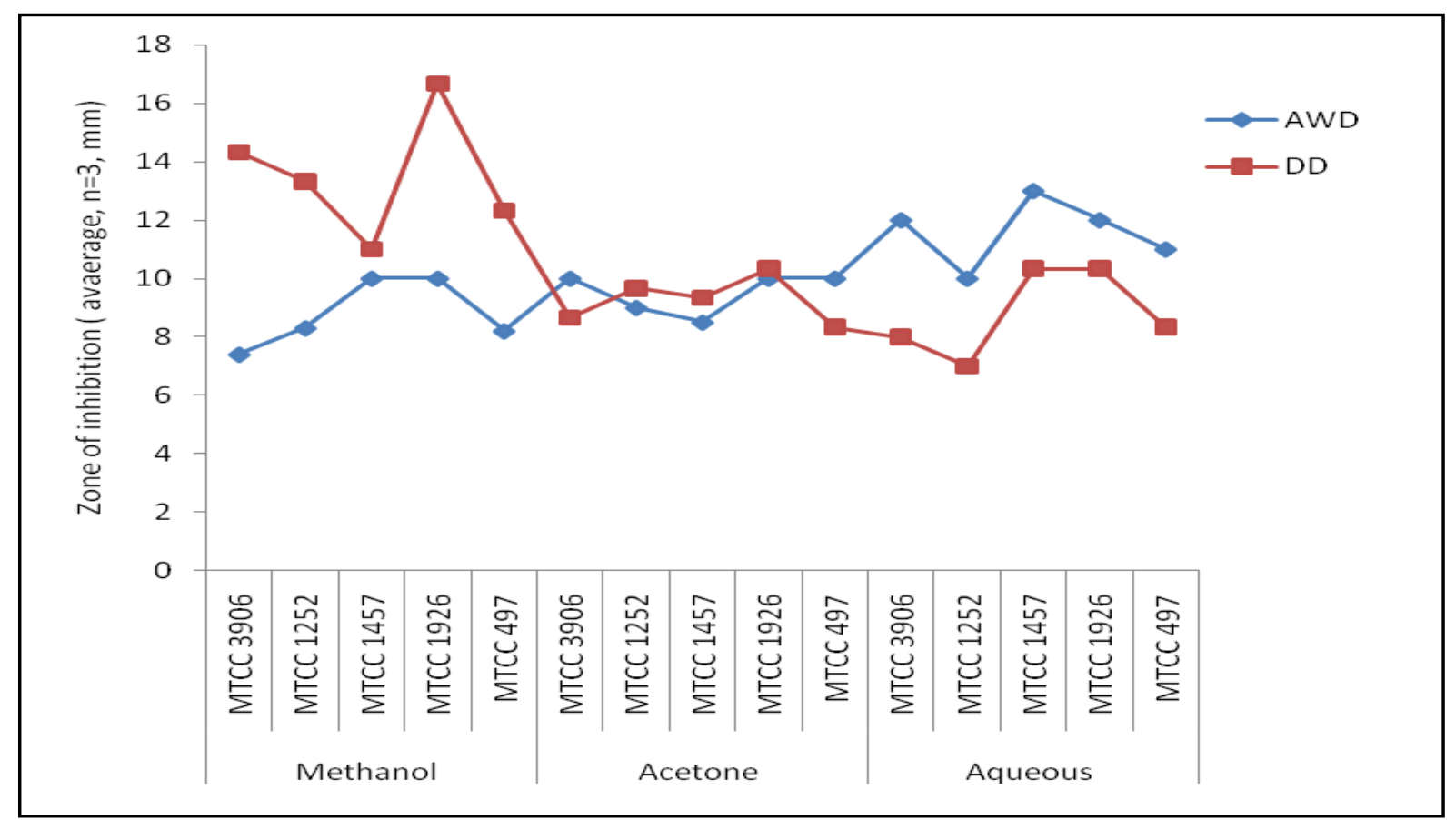

Fig. 2: Comprative antibacterial activity (Zone of inhibition) of different extracts of the leaves of exprimantal plant 
Table 4: Estimation of MIC values of Gymnopetalum chinense extract against pathogenic bacterial strain

\begin{tabular}{|c|c|c|c|c|c|}
\hline $\begin{array}{l}\text { Plant } \\
\text { extracts }\end{array}$ & МТСС 3906 & MTCC 1252 & MTCC 1457 & МТСC 1926 & MTCC 497 \\
\hline GCM & $300 \mu \mathrm{g} / \mathrm{ml}$ & $300 \mu \mathrm{g} / \mathrm{ml}$ & $300 \mu \mathrm{g} / \mathrm{ml}$ & $200 \mu \mathrm{g} / \mathrm{ml}$ & $200 \mu \mathrm{g} / \mathrm{ml}$ \\
\hline GCA & $400 \mu \mathrm{g} / \mathrm{ml}$ & $400 \mu \mathrm{g} / \mathrm{ml}$ & $400 \mu \mathrm{g} / \mathrm{ml}$ & $300 \mu \mathrm{g} / \mathrm{ml}$ & $300 \mu \mathrm{g} / \mathrm{ml}$ \\
\hline GCAq & $500 \mu \mathrm{g} / \mathrm{ml}$ & $500 \mu \mathrm{g} / \mathrm{ml}$ & $500 \mu \mathrm{g} / \mathrm{ml}$ & $500 \mu \mathrm{g} / \mathrm{ml}$ & $500 \mu \mathrm{g} / \mathrm{ml}$ \\
\hline S1 & $3.125 \mu \mathrm{g} / \mathrm{ml}$ & $3.125 \mu \mathrm{g} / \mathrm{ml}$ & $3.125 \mu \mathrm{g} / \mathrm{ml}$ & $3.125 \mu \mathrm{g} / \mathrm{ml}$ & $3.125 \mu \mathrm{g} / \mathrm{ml}$ \\
\hline $\mathrm{S} 2$ & $100 \mu \mathrm{g} / \mathrm{ml}$ & $50 \mu \mathrm{g} / \mathrm{ml}$ & $50 \mu \mathrm{g} / \mathrm{ml}$ & $12.5 \mu \mathrm{g} / \mathrm{ml}$ & $12.5 \mu \mathrm{g} / \mathrm{ml}$ \\
\hline $\begin{array}{l}\text { Inoculums } \\
\text { control }\end{array}$ & $\begin{array}{l}\text { Growth in all } \\
\text { concentration }\end{array}$ & $\begin{array}{l}\text { Growth in all } \\
\text { concentration }\end{array}$ & $\begin{array}{l}\text { Growth in all } \\
\text { concentration }\end{array}$ & $\begin{array}{l}\text { Growth in all } \\
\text { concentration }\end{array}$ & $\begin{array}{l}\text { Growth in all } \\
\text { concentration }\end{array}$ \\
\hline $\begin{array}{l}\text { Broth } \\
\text { control }\end{array}$ & No Growth & No Growth & No Growth & No Growth & No Growth \\
\hline DMSO & $\begin{array}{l}\text { Growth in all } \\
\text { concentration }\end{array}$ & $\begin{array}{l}\text { Growth in all } \\
\text { concentration }\end{array}$ & $\begin{array}{l}\text { Growth in all } \\
\text { concentration }\end{array}$ & $\begin{array}{l}\text { Growth in all } \\
\text { concentration }\end{array}$ & $\begin{array}{l}\text { Growth in all } \\
\text { concentration }\end{array}$ \\
\hline
\end{tabular}

(MTCC: Microbial Type Culture Collection; MTCC 3906: Vibrio cholera; MTCC 1252: Salmonela enteric typhi; MTCC 1457: Shigella flexneri; MTCC 1926: Streptococcus pyogenes; MTCC 497: Streptococcus mutans; MTCC 2513: Candida albicans; GCM: Gymnopetalum chinense methanol extract; GCA: Gymnopetalum chinense acetone extract; GCAq: Gymnopetalum chinense aqueous extract; DMSO: Dimethyl Sulfo-oxide; S1: Ampicillin; S2: Kanamycin)

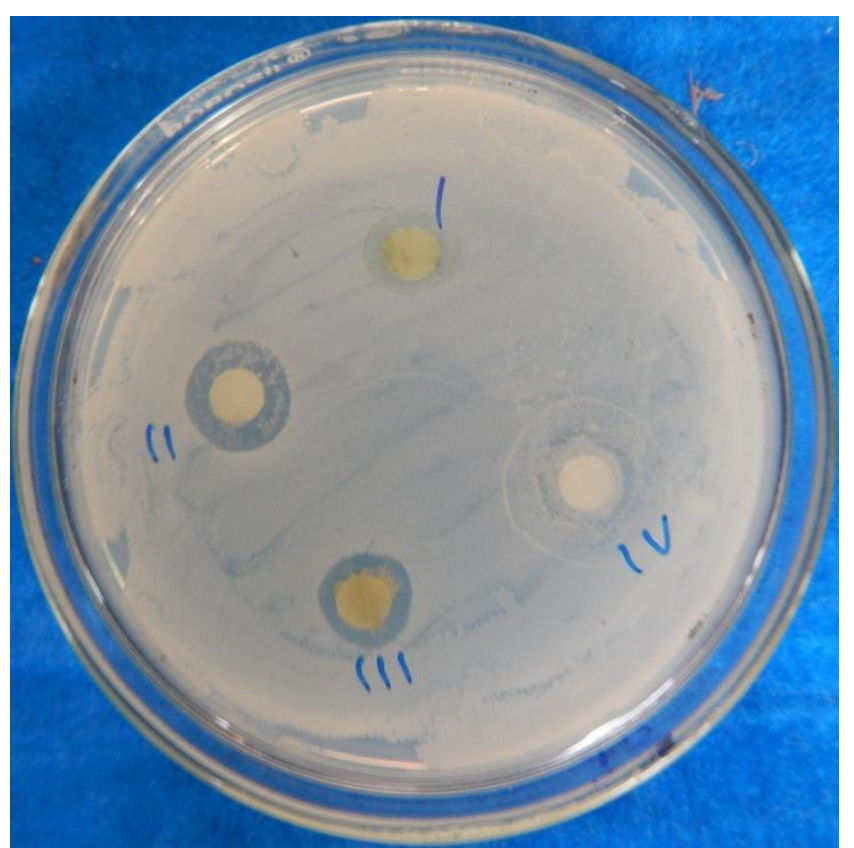

Fig. 3: Antibacterial activity of $G$. chinense against MTCC 926 sing DD assay (20 $\mu \mathrm{g} / \mathrm{Disc})$, I: Methanol, II: Methanol extract, III: Acetone extract, IV: Acetone

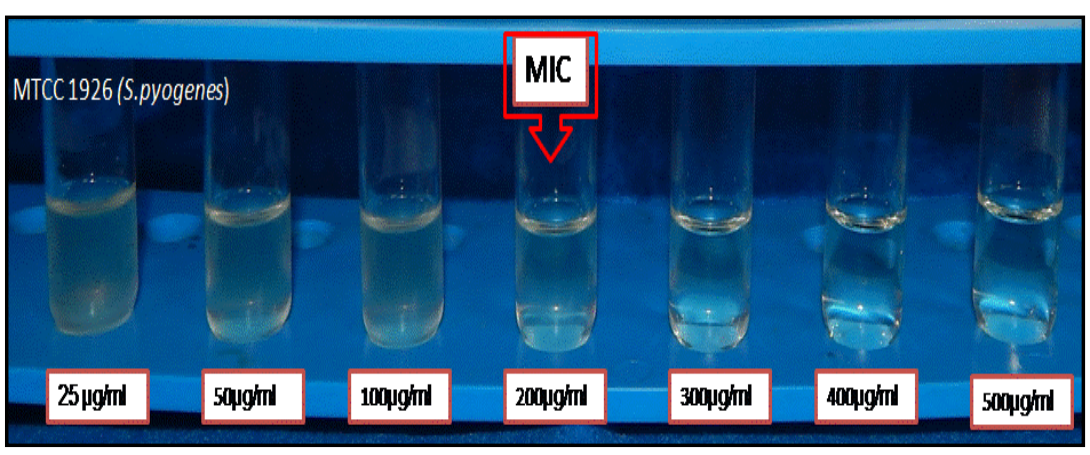

Fig. 4: MIC values of methanol extract against S. pyogenes (MTCC 1926) using broth dilution assay 
Antibacterial activity of Gymnopetalum chinense

\section{CONCLUSIONS}

The results of the present investigation, provides a base line to screen the new bioactive compounds and to formulate new drugs to fight against anti-microbial resistance by the board spectrum pathogenic microorganisms. Present study might be useful to supplement scientific information to establish tribal claims for the presence of phytocompounds and medicinal values in the plant species. Further research is needed to document the detail bioactive compounds present in such wild plants predominant in Odisha, India and their probable use against known pathogenic microorganisms for the development of antimicrobial drugs useful to pharmaceutical industries.

\section{ACKNOWLEDGEMENTS}

This work was supported by Korea Institute of Planning and Evaluation for Technology in Food, Agriculture, Forestry and Fisheries(IPET) through the Agricultural Research Center Project, funded by Ministry of Agriculture, Food and Rural Affairs(MAFRA)(710003-07-7-SB120), Republic of Korea. Authors are grateful to HOD, Department of Botany, Ravenshaw University, Cuttack, Odisha, India for providing laboratory facilities. Author (PK) thankful to Director, NERIST, and Head, Department of Forestry, NERIST (Deemed University), Nirjuli (Itanagar), Arunachal Pradesh, India.

\section{REFERENCES}

1. Wise R. Regenerating antibacterial drug discovery and development, the urgent need for antibacterial agents. J. Antimicrob Chemo. 2011; 66: 1939-1940.

2. Nash RJ, Kato A, Yu CY, Fleet GM. Iminosugars as therapeutic agents: recent advances and promising trends. Future Med. Chem. 2011; 3: 1513-1521.

3. Osbourn AE. Performed antimicrobial compounds and plant defence against fungal attack. Plant Cell. 1996; 8: 1821-1831.

4. Alper J. Effort to combat microbial resistance lags. Amer. Sci. Microb. News. 1998, 64: 440-441.

5. Eisenberg DM, Kessler RC, Foster C, Norlock FE, Calkins DR, Delbanco TL. Unconvential medicine in the United States: prevalence, costs and patterns of use. New Eng. J. Med. 1993, 328: 246-252.

6. Moerman DE. An analysis of the food plants and drug plants of native North A. $J$. Ethnopharmacol. 1996, 52: 1-22.

7. Osman K, Evangelopoulos D, Basavannacharya C. An antibacterial from Hypericum acmosepalum inhibis ATP-dependent MurE ligase from Mycobacterium tuberculosis. Int. J. Antimicrob. Agents. 2012, 39: 124-129.

8. Fischbash MA, Walsh CT. Antibiotics for emerging pathogens. Sci. 2009, 325: 10891093.

9. Dianella S. Plant derived antimicrobial compounds: alternatives to antibiotic. Future Microbiol. 2012, 7: 979-990.

10. Ginsburg H, Deharo E. A cell for using natural compounds in the development of new antimalarial treatments- an introduction. Malarial J. 2011, 10: 1-11.

11. Saxena HO, Brahmam M. The Flora of Orissa. Orissa Forest Development Corporation Ltd. and Regional Research Laboratory, Bhubaneshwar. 1995-1997, 3: 1940-1956.

12. Mondal KK, Kar T, Rout NC, Biswal AK. Gymnopetalum Arn. and Gynostemma Blume (Cucurbitaceae): Two generic records for Odisha. Life Sci. Leaflets. 2012, 1: 5760.

13. Pradheep K, Pani DR, Bhandari DC. Addition of Gymnopetalum chinense (Lour.) Merr. To the flora of Odisha. Ind. Forester. 2013, 139: 465-466. 
14. De Wilde WJJO, Duyfjes BEE. Review of the genus Gymnopetalum (Cucurbitaceae). Blumea. 2006, 51: 281-296.

15. Clarke CB. Cucurbitaceae. In: the flora of british India (J.D. Hooker, Edit.) Vol. 2. L. Reeve, London, 1879.

16. Haines HH. The Botany of Bihar and Orissa. Adlard \& Son \& West Newman Ltd., London, 1921-1925, 5-6: 1115-1124.

17. Saxena HO, Brahmam M. The Flora of Orissa, Vol 1, Regional Research Laboratry (CSIR), Bhubaneswar and Orissa Forest Development Corporation Ltd., Bhubaneswar, 1994.

18. Pullaiah T, Ramamurthy K, Karuppusamy S. Flora of Eastern Ghats: hill ranges of south east India. Vol. 3 Rosaceae-Asteraceae, Regency Publication, New Delhi, 2007.

19. Misra RC, Kumar S, Pani DR, Bhandari DC. Empirical tribal claims and correlation with bioactive compounds: a study on Celastrus paniculata Willd., a vulnerable medicinal plant of Odisha. Ind. J. Trad. Knowl. 2012, 11: 615-622.

20. Tiwari P, Kumar B, Kaur M, Kaur G, Kaur H. Phytochemical screening and extraction: a review. Int. Pharmaceut. Sci. 2011, 1: 98-106.

21. Kumar S. Qualitative studies of bioactive compounds in leaf of Tylophora indica (Burm.f.) Merr. Int. J. Res. Pharmaceut. Biomed. Sci. 2011, 2: 1188-1192.

22. Sofowora A. Medicinal plants and traditional medicine in Africa. Spectrum Books limited. Ibadan, 1993.

23. Allen KL, Molan PC, Reid GM. A survey of the antibacterial activity of some New Zealand honeys. J. Pharm. Pharmac. 1991, 43: 817-822.

24. Amanda JD, Bhat N, Ruth AK, Katherine LO, David RM. Disc Diffusion Bioassays for the detection of antibiotic activity in body fluids: applications for the pneumonia etiology research for child health project. Clin. Inf. Dise. 2012, 54: 159-164.

25. Rai US, Isloor AM, Shetty P, Vijesh AM, Prabhu N, Isloor S, et al. Novel Chromeno (2,3-b)-pyrimidine derivatives as potential anti-microbial agents, European J. Med. Chem. 2010, 45: 2695-2699.

26. Muthamperumal C, Parthasarathy N. Angiosperms, climbing plants in Tropical forests of southern Eastern Ghats, Tamil Nadu, India, Checklist. 2009, 5: 92-111.

27. Orhan, DD, Ozcelik, B, Ozgen, S, Ergun, F. Antibacterial, antifungal, and antiviral activities of some flavonoides. Microbiol. Res. 2010, 165: 496-504.

28. Cowan MM. Plant products as antimicrobial agents. Clinical Microbiol. Rev. 1999, 12: 564-582.

29. Mashour NH, Lin IG, Frishman WH. Herbal medicine for the treatment of cardiovascular disease. Archive Internal Med. 1998, 158: 2225-2234.

30. Kumar A, De T, Mishra AK. Oleandran: a cardiac glycosides with potent cytotoxicity. Pharmacognosy Reviews. 2013. 7(14): 131-139.

31.Gaikwad SB, Mohan GK, Rani MS. Phytochemical for diabetes management. Pharmaceutical Crops. 2014. 5: 11-28. 